\title{
Studies on Effect of Tree Lopping Intensities and Organic Manures on Soil Physico-Chemical Properties in Morus-Maize Based Agroforestry System
}

\author{
M.C. Shashi Kumar ${ }^{1 *}$, C.L. Thakur ${ }^{1}$, P.V. Dhanyashri ${ }^{2}$, \\ Stanzin Namdol $^{1}$ and S. S. Inamatti ${ }^{3}$ \\ ${ }^{1}$ Dr. Y S Parmar University of Horticulture and Forestry, Nauni, Solan (H P), India \\ ${ }^{2}$ Birsa Agriculture University, Ranchi, Jharkhand, India \\ ${ }^{3}$ College of Forestry, Sirsi UAS Dharwad, India \\ *Corresponding author
}

\section{A B S T R A C T}

K e y w o r d s
Agroforestry,
Canopy
management,
$\begin{aligned} & \text { Lopping, Organic } \\ & \text { manures, Soil } \\ & \text { properties, Edaphic } \\ & \text { processes etc. }\end{aligned}$
Article Info
$\begin{aligned} & \text { Accepted: } \\ & \text { 26 May } 2020 \\ & \text { Available Online: } \\ & \text { 10 June } 2020\end{aligned}$

Keywords

Agroforestry,

Canopy

management

manures, Soil

properties, Edaphic

processes etc.

10 June 2020
Agroforestry a complex land use system both ecologically and economically have innumerous role to play in conservation of natural resources along with its economic viability. Various tree canopy management activities like pruning and lopping along with applied resources have significant effect on soil. Litter fall, decomposition, leaching and residual effect have great potential on soil health of the system. Present system involving lopped trees and organically mannured crop have shown varying effect on soil properties. Tree lopping had significantly affected various soil properties where the maximum EC $\left(0.13 \mathrm{dS}^{-1} \mathrm{~m}\right)$, Organic carbon percentage $(1.33 \%)$ and available Nitrogen $(418.02 \mathrm{~kg} / \mathrm{ha})$ were observed in $T_{0}$ (No lopping). Among organic manures $S_{1}(F Y M)$ has shown maximum soil $\mathrm{pH}(7.08)$ and $\mathrm{EC}\left(0.12 \mathrm{dS}^{-1} \mathrm{~m}\right)$ whereas maximum organic carbon was obtained in both $S_{1}$ and $S_{3}(1.37 \%)$, available nitrogen $(437.89 \mathrm{~kg} / \mathrm{ha})$ was found to be maximum in treatment $\mathrm{S}_{3}$ (Vermicompost) and maximum available soil phosphorus $(48.17 \mathrm{~kg} / \mathrm{ha}$ ) and available soil potassium (327.93 kg/ha) was observed in $S_{2}$ (Jeevamruth). Interaction effect of lopping and organic manure $(\mathrm{T} * \mathrm{~S})$ has shown differential results. Overall application of organic manures has shown improvement in soil properties and lopping had differential effect on soil due to varied leaf fall and edaphic processes.

\section{Introduction}

Agroforestry being multi component farming it is having more pressure on land for resources than any monocropping where the requirement is less. Whereas, in agroforestry soil nutrients are better compared to any other systems due to closed nutrient cycle and sustainable nutrient base because of perennial component. Trees add organic matter to the soil system in various manners like litter fall, dead root additions that is chief source of substrate for a vast range of organisms responsible for soil biological activity and improves the soil health and fertility. Plants get most of their nutrients from soil for their growth and development but due to land degradation and overuse of land, the present- 
day land is not capable of supplying such essential nutrients to plants hence, artificial fertilization is commonly done. Chemical fertilizers no doubt have boosted the crop growth, yield and productivity, but to larger extent they are also responsible for soil deterioration and soil pollution. But over usage of chemical fertilizers the land is getting degraded day by day in its health and fertility status hence, the use of chemical fertilizers has to be minimized and organic manures has to be used as an alternative for chemical fertilizers in order to replenish the soil health and fertility. Integration of different sources of nutrients has positive effect on soil health along sustained productivity and undisturbed congenial environment for soil flora and fauna. Land degradation can be easily fought by using integrated measures like using organic manure and along with long lasting solutions like agroforsetry which conserve soil and improve nutrient pool status by closed nutrient cycling. Agroforestry holds considerable potential as a major landmanagement alternative for conserving soil as well as maintaining soil fertility and productivity. Presence of trees on farm lands increases organic matter through leaf litter, reduce nutrient losses through run off, leaching and enhance nutrient use efficiency. But once agroforestry model gets older it needs various canopy management activities in order to get good growth of intercrop. Whereas, effect of tree canopy management activities on soil is very less studied aspect hence present study is conducted to spread limelight on this aspect of agroforestry.

\section{Materials and Methods}

Field study was conducted in agroforestry experimental farm area of Dr. Y.S.Parmar University of Horticulture and Forestry, Nauni, Solan during the year 2018-2019 with lopping as main and organic manures as sub treatment. Before the starting of experiment soil samples were collected from field and analyzed for later comparison. Randomized Complete block design was laid out with three replications under mulberry trees that are spaced $9 \mathrm{~m}^{*} 3 \mathrm{~m}$ apart and are lopped at varying intensities ( $\mathrm{T}_{0}$ (unlopped /Control), $\mathrm{T}_{1}$ $(25 \%), \mathrm{T}_{2}(50 \%)$ and $\mathrm{T}_{3}(75 \%)$. Before sowing the maize seeds three trees in each row were selected for lopping at the intensities of $(0 \%, 25 \%, 50 \%$ and $75 \%)$ and were lopped according to subjective judgment in all three rows and four beds of size $4 \mathrm{~m}^{*} 2 \mathrm{~m}$ were prepared under each lopping intensity and in case of control no lopping was carried out just four beds were prepared. Under each lopping intensity different organic manures

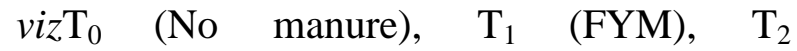
(Jeevamruth) and $\mathrm{T}_{3}$ (Vermicompost) were applied as per recommended dose (Quantity of organic manures were calculated on $\mathrm{N}$ equivalent basis). Manures were equally distributed and mixed thoroughly. Maize seeds were sown at spacing $45 * 20 \mathrm{~cm}$ spacing during second week of June 2018 as a kharif crop in the beds prepared in interspace between two rows of trees. Crop was irrigated and cultivated as per standard package of practices and was harvested after maturity.

Total treatment combinations were $T_{0} S_{0}$, $\mathrm{T}_{0} \mathrm{~S}_{1}, \mathrm{~T}_{0} \mathrm{~S}_{2}, \mathrm{~T}_{0} \mathrm{~S}_{3}, \mathrm{~T}_{1} \mathrm{~S}_{0}, \mathrm{~T}_{1} \mathrm{~S}_{1}, \mathrm{~T}_{1} \mathrm{~S}_{2}, \mathrm{~T}^{1} \mathrm{~S}_{3}, \mathrm{~T}_{2} \mathrm{~S}_{0}$, $\mathrm{T}_{2} \mathrm{~S}_{1}, \mathrm{~T}_{2} \mathrm{~S}_{2}, \mathrm{~T}_{2} \mathrm{~S}_{3}, \mathrm{~T}_{3} \mathrm{~S}_{0}, \mathrm{~T}_{3} \mathrm{~S}_{1}, \mathrm{~T}_{3} \mathrm{~S}_{2}, \mathrm{~T}_{3} \mathrm{~S}_{3}$. The crop was harvested after its maturity and Four soil samples were collected randomly from each plot of depth $0-15 \mathrm{~cm}$ and composite sample was prepared by mixing the four samples from every plot. Samples were air dried, crushed thoroughly and passed through $2 \mathrm{~mm}$ sieve. After that further analysis was carried out as per following methods. Obtained data was analyzed using OPSTAT by subjecting data to statistical analysis as per Gomez and Gomez (1984) with 5\% critical difference. 


\section{Results and Discussion}

Trees lopping intensities and addition of different organic manures to the land have shown varying effects as the various soil process like decomposition, release and uptake of nutrients, leaching and residual effect on soil properties. Among the lopping treatments the tree lopping treatment $\mathrm{T} 3(75 \%$ lopping) resulted in the minimum soil $\mathrm{pH}$ i.e., 6.74 and the lopping treatment T0 $(0 \%$ lopping) resulted in the maximum soil $\mathrm{pH}$ i.e., 6.90 among the organic manure treatments, the soil $\mathrm{pH}$ was minimum in treatment $\mathrm{S} 2$ (Jeevamruth) i.e., 6.60 and the maximum soil $\mathrm{pH}$ was attained in treatment S1 (FYM) i.e., 7.08 due to more bases availability which was statistically at par with S3 (Vermicompost) i.e., 6.90. Combination of tree lopping and organic manure treatments was found to be non-significant with maximum soil $\mathrm{pH}$ being attained in treatment combination TOS1 $(0 \%$ lopping intensity + FYM) i.e., 7.23 and treatment combination $\mathrm{T} 3 \mathrm{~S} 2$ (75\% lopping intensity + Jeevamruth) attained minimum soil pH i.e., 6.53. Srikant et al., (2000) for organic manures and Kahi et al., (2009) for tree lopping also reported similar results. Effect of Lopping on soil $\mathrm{Ph}$ was not observed as it needs more time to alter.

Maximum soil EC $\left(\mathrm{dS} \mathrm{m}^{-1}\right)$ was recorded in T0(no lopping) i.e., 0.12 which was at par with $\mathrm{T} 1$ (25\% lopping intensity) i.e., 0.12 and the minimum soil EC ( $\left.\mathrm{dS} \mathrm{m}^{-1}\right)$ was obtained in treatment $\mathrm{T} 3(75 \%$ lopping intensity) i.e., 0.11 . Organic manure applications the maximum soil EC $\left(\mathrm{dS} \mathrm{m}^{-1}\right)$ was obtained in organic manure treatment S1(FYM) application i.e., 0.12 and as at par with manure treatment S2 (Jeevamruth) i.e., 0.12 and the minimum soil EC ( $\mathrm{dS} \mathrm{m} \mathrm{m}^{-1}$ ) was obtained in S0 (no manure) i.e., 0.11 . Combined effect of both lopping treatment and organic manures has found to be nonsignificant for soil EC ( $\left(\mathrm{dS} \mathrm{m}^{-1}\right)$ and the in treatment combination T0S1 (0\% lopping intensity + FYM) resulted in maximum i.e., 0.11 soil EC $\left(\mathrm{dS} \mathrm{m}^{-1}\right)$ and treatment combination $\mathrm{T} 3 \mathrm{~S} 0$ (75\% lopping intensity + no manure) attained minimum soil EC (dS m1) i.e., 0.11. The difference in soil EC was may be due to differential nutrient status of organic manures and differential litter fall and decomposition by tree canopy. Similar results were obtained by Varalaxmi et al., (2005) and Gathala et al., (2007).

Among the lopping treatments the tree lopping treatment T3 (75\% lopping) resulted in the minimum soil organic carbon (\%)i.e., 1.23 and the lopping treatment T0 $(0 \%$ lopping) resulted in the maximum soil organic carbon $(\%)$ i.e., 1.33 the soil organic carbon(\%) was significantly affected due to the litter fall, decomposition and leaching of soil nutrients. Soil organic carbon (\%) was minimum in treatment S0 (No manure) i.e., 1.06 and the maximum soil organic carbon (\%) was attained in treatment S1 (FYM) i.e., 1.37. FYM affected soil organic carbon (\%) due to presence of more carbon source in FYM and no manure application had nil carbon source.

Combination was found to be non-significant with maximum soil organic carbon (\%) being attained in treatment combination $\mathrm{T} 0 \mathrm{~S} 1(0 \%$ lopping intensity + FYM) i.e., 1.43 and treatment combination $\mathrm{T} 3 \mathrm{~S} 0(75 \%$ lopping intensity + No manure) attained minimum soil organic carbon (\%) i.e., 1.01. Difference in soil organic carbon due to lopping was a result of decreased litter fall and decomposition in lopped trees than unlopped trees. Similar results for tree lopping were obtained by Prasad et al., (2016) and Emire et al., (2018).

Available nitrogen for tree lopping treatment T3 (75\% lopping) resulted in the minimum available nitrogen (kg-1ha) in soil i.e., $405.7 \mathrm{~kg}$ and the lopping treatment T0 (0\% lopping) resulted in the maximum soil available 
nitrogen $\left(\mathrm{kg}^{-1}\right.$ ha) i.e., $418.05 \mathrm{~kg}$. Whereas the application of organic manures significantly affected the available nitrogen(kg-1ha) in soil among the organic manure treatments, the soil available nitrogen(kg-1ha) was minimum in treatment S0 (No manure) i.e., $341.0 \mathrm{~kg}$ and the maximum available nitrogen $\left(\mathrm{kg}^{-1} \mathrm{ha}\right)$ in soil was attained in treatment S3 (Vermicopmost) i.e., $437.89 \mathrm{~kg}$ organic manure has shown significant variation in soil due to bulk posting of organic matter rich in nitrogen which enhanced microbial activity in the soil and thereby greater conversion of organically bound nitrogen to inorganic form by the activities of microbes.

Combination of tree lopping and organic manure treatments was found to be significant with maximum available nitrogen $\left(\mathrm{kg}^{-1} \mathrm{ha}\right)$ in soil being attained in treatment combination $\mathrm{T}_{0} \mathrm{~S}_{3}(0 \%$ lopping intensity + Vermicompost $)$ i.e. $447.2 \mathrm{~kg}$ and treatment combination $\mathrm{T}_{3} \mathrm{~S}_{0}(75 \%$ lopping intensity + No manure) attained minimum available nitrogen $\left(\mathrm{kg}_{-}{ }^{1} \mathrm{ha}\right)$ in soil i.e. $337.6 \mathrm{~kg}$. The rate of mineralization and uptake of nutrients was maximum under $75 \%$ lopped trees hence the available nitrogen in soil was minimum after harvest of maize crop. Similar results for increase in nitrogen with increasing tree shade was reported by Kaushal et al., (2012) and Sirohi and Bangarwa (2015).

Among the lopping treatments, the tree lopping treatment $\mathrm{T}_{3}$ (75\% lopping) resulted in the minimum available phosphorus in soil $\left(\mathrm{kg}^{-1}\right.$ ha) i.e. $41.56 \mathrm{~kg}$ and the lopping treatment $\mathrm{T}_{0}(0 \%$ lopping) resulted in the maximum available phosphorus in soil $\mathrm{kg}^{-1}$ ha) i.e. 42.49. Whereas the application of organic manures significantly affected the available phosphorus in soil $\left(\mathrm{kg}^{-1} \mathrm{ha}\right)$ among the organic manure treatments, the available phosphorus in soil $\left(\mathrm{kg}^{-1}\right.$ ha) was maximum in treatment $\mathrm{S}_{2}$ (Jeevamruth) i.e. $48.17 \mathrm{~kg}$, minimum available phosphorus in soil (kgha) was attained in treatment $S_{0}$ (No manure) i.e. $31.32 \mathrm{~kg}$. The organic manure has shown significant variation with Jeevamruth resulting in maximum available phosphorus in soil (kg- ${ }^{1}$ ha) due to presence of many beneficial microorganisms that increase phosphorus availability and treatment $\mathrm{S}_{3}$ (Vermicompost) being at par with maximum followed by FYM and no manure application (Table 1 and 2).

Table.1 Soil physico-chemical analysis: Methods and instruments used

\begin{tabular}{|c|c|c|c|c|}
\hline $\begin{array}{l}\text { Sr. } \\
\text { No. }\end{array}$ & Parameter & Method employed & $\begin{array}{c}\text { Instrument/apparat } \\
\text { us used }\end{array}$ & $\begin{array}{l}\text { Soil properties before } \\
\text { sowing }(0-15 \mathrm{~cm})\end{array}$ \\
\hline 1. & pH (1:2) & $\begin{array}{l}\text { 1:2 soil water suspension } \\
\text { (Jackson, 1973) }\end{array}$ & $\mathrm{pH}$ meter & 6.58 \\
\hline 2. & $\begin{array}{l}\text { Electrical conductivity } \\
\left(\mathrm{dS} \mathrm{m}^{-1}\right)\end{array}$ & $\begin{array}{c}\text { 1:2 soil water suspension } \\
\text { (Jackson, 1973) }\end{array}$ & $\begin{array}{c}\text { Electrical } \\
\text { conductivity meter }\end{array}$ & 0.11 \\
\hline 3. & Organic carbon (\%) & $\begin{array}{c}\text { Rapid titration method } \\
\text { (Walkley and Black, 1934) }\end{array}$ & & 1.09 \\
\hline 4. & $\begin{array}{l}\text { Available Nitrogen (kg } \\
\left.\qquad \text { ha }^{-1}\right)\end{array}$ & $\begin{array}{c}\text { Alkaline potassium } \\
\text { permanganate method } \\
\text { (Subbiah and Asija, 1956) }\end{array}$ & $\begin{array}{c}\text { Kjeldhal distillation } \\
\text { unit }\end{array}$ & 338.4 \\
\hline 5. & $\begin{array}{l}\text { Available phosphorus } \\
\qquad\left(\mathrm{kg} \mathrm{ha}^{-1}\right)\end{array}$ & Olsen et al., (1954) & Spectronic 20-D+ & 32.92 \\
\hline 6. & $\begin{array}{c}\text { Available potassium } \\
\qquad\left(\mathrm{kg} \mathrm{ha}^{-1}\right)\end{array}$ & $\begin{array}{l}\text { Neutral } 1 \mathrm{~N} \text { ammonium } \\
\text { acetate solution method } \\
\text { (Merwin and Peech, 1951) }\end{array}$ & Flame photometer & 268.2 \\
\hline
\end{tabular}


Table.2 Effect of tree lopping intensities and organic manures on soil properties

\begin{tabular}{|c|c|c|c|c|c|c|c|c|c|c|c|c|}
\hline \multirow{2}{*}{$\begin{array}{l}\text { Parameters } \\
\text { Treatments } \\
\text { /Manures }\end{array}$} & \multicolumn{4}{|c|}{ Soil pH } & \multicolumn{4}{|c|}{ Electrical conductivity $\left(\mathrm{dS} \mathrm{m}^{-1}\right)$} & \multicolumn{4}{|c|}{ Organic carbon $(\%)$} \\
\hline & $\begin{array}{c}\mathrm{S}_{0} \\
\text { (No } \\
\text { man) }\end{array}$ & $\begin{array}{c}\mathrm{S}_{1} \\
(\mathrm{FYM})\end{array}$ & $\begin{array}{c}\mathrm{S}_{2} \\
\text { (Ver) }\end{array}$ & $\begin{array}{c}\mathrm{S}_{3} \\
(\text { Jeev })\end{array}$ & $\begin{array}{c}\mathrm{S}_{0} \\
\text { (No } \\
\text { man) }\end{array}$ & $\begin{array}{c}\mathrm{S}_{1} \\
(\mathrm{FYM})\end{array}$ & $\begin{array}{c}\mathrm{S}_{2} \\
(\mathrm{Ver})\end{array}$ & $\begin{array}{c}\mathrm{S}_{3} \\
\text { (Jeev) }\end{array}$ & $\begin{array}{c}\mathrm{S}_{0} \\
\text { (No } \\
\text { man) }\end{array}$ & $\begin{array}{c}\mathrm{S}_{1} \\
(\mathrm{FYM})\end{array}$ & $\begin{array}{c}\mathrm{S}_{2} \\
(\mathrm{Ver})\end{array}$ & $\begin{array}{c}\mathrm{S}_{3} \\
\text { (Jeev) }\end{array}$ \\
\hline $\mathbf{T}_{0}(\mathbf{0 \%})$ & 6.73 & 7.23 & 6.70 & 6.97 & 0.12 & 0.13 & 0.12 & 0.12 & 1.12 & 1.43 & 1.38 & 1.40 \\
\hline $\mathrm{T}_{1}(25 \%)$ & 6.67 & 7.07 & 6.63 & 6.97 & 0.12 & 0.12 & 0.12 & 0.12 & 1.09 & 1.44 & 1.37 & 1.40 \\
\hline $\mathbf{T}_{2}(\mathbf{5 0 \%})$ & 6.60 & 7.03 & 6.53 & 6.83 & 0.11 & 0.12 & 0.12 & 0.11 & 1.02 & 1.35 & 1.23 & 1.35 \\
\hline $\mathbf{T}_{3}(\mathbf{7 5 \%})$ & 6.60 & 7.00 & 6.53 & 6.83 & 0.10 & 0.12 & 0.11 & 0.11 & 1.01 & 1.27 & 1.30 & 1.32 \\
\hline Mean & 6.68 & 7.08 & 6.60 & 6.90 & 0.11 & 0.12 & 0.12 & 0.11 & 1.06 & 1.37 & 1.32 & 1.37 \\
\hline \multirow[t]{3}{*}{$\mathrm{CD}_{0.05}$} & \multirow{3}{*}{\multicolumn{3}{|c|}{$\begin{array}{c}\mathbf{T} \\
\mathbf{S} \\
\mathbf{T x S}\end{array}$}} & NS & \multirow{3}{*}{\multicolumn{3}{|c|}{$\begin{array}{c}\mathbf{T} \\
\mathbf{S} \\
\mathbf{T x S}\end{array}$}} & 0.03 & \multirow{3}{*}{\multicolumn{3}{|c|}{$\begin{array}{c}\mathbf{T} \\
\mathbf{S} \\
\mathbf{T x S}\end{array}$}} & 0.03 \\
\hline & & & & 0.09 & & & & 0.03 & & & & 0.05 \\
\hline & & & & NS & & & & NS & & & & NS \\
\hline
\end{tabular}

\begin{tabular}{|c|c|c|c|c|c|c|c|c|c|c|c|c|}
\hline \multirow{2}{*}{$\begin{array}{l}\text { Parameters } \\
\text { Treatments } \\
\text { /Manures }\end{array}$} & \multicolumn{4}{|c|}{ Available Nitrogen $\left(\mathrm{kg} \mathrm{ha}^{-1}\right)$} & \multicolumn{4}{|c|}{ Available phosphorus $\left(\mathrm{kg} \mathrm{ha}^{-1}\right)$} & \multicolumn{4}{|c|}{ Available potassium $\left(\mathrm{kg} \mathrm{ha}^{-1}\right)$} \\
\hline & $\begin{array}{c}\mathrm{S}_{0} \\
(\mathrm{No} \\
\operatorname{man})\end{array}$ & $\begin{array}{c}\mathrm{S}_{1} \\
(\mathrm{FYM})\end{array}$ & $\begin{array}{c}\mathrm{S}_{2} \\
\text { (Ver) }\end{array}$ & $\begin{array}{c}\mathrm{S}_{3} \\
(\text { Jeev) }\end{array}$ & $\begin{array}{c}\mathrm{S}_{0} \\
\text { (No } \\
\text { man) }\end{array}$ & $\begin{array}{c}\mathrm{S}_{1} \\
(\mathrm{FYM})\end{array}$ & $\begin{array}{c}\mathrm{S}_{2} \\
(\mathrm{Ver})\end{array}$ & $\begin{array}{c}\mathrm{S}_{3} \\
\text { (Jeev) }\end{array}$ & $\begin{array}{c}\mathrm{S}_{0} \\
\text { (No } \\
\operatorname{man})\end{array}$ & $\begin{array}{c}\mathrm{S}_{1} \\
(\mathrm{FYM})\end{array}$ & $\begin{array}{c}\mathrm{S}_{2} \\
\text { (Ver) }\end{array}$ & $\begin{array}{c}\mathrm{S}_{3} \\
\text { (Jeev) }\end{array}$ \\
\hline $\mathrm{T}_{0}(0 \%)$ & 343.73 & 441.54 & 439.67 & 447.26 & 31.59 & 43.43 & 48.86 & 46.08 & 271.06 & 322.66 & 329.40 & $\begin{array}{c}328.1 \\
0\end{array}$ \\
\hline $\mathrm{T}_{1}(\mathbf{2 5 \%})$ & 341.70 & 435.26 & 444.40 & 437.36 & 31.25 & 43.20 & 48.10 & 45.82 & 270.13 & 321.56 & 328.60 & $\begin{array}{c}327.2 \\
6\end{array}$ \\
\hline $\mathbf{T}_{2}(\mathbf{5 0} \%)$ & 341.06 & 430.33 & 434.19 & 435.66 & 31.06 & 42.40 & 48.43 & 45.36 & 270.60 & 320.80 & 327.80 & $\begin{array}{c}325.0 \\
0\end{array}$ \\
\hline $\mathrm{T}_{3}(\mathbf{7 5 \%})$ & 337.60 & 427.63 & 426.63 & 431.26 & 31.36 & 42.88 & 47.28 & 44.73 & 266.23 & 321.93 & 325.93 & $\begin{array}{c}322.6 \\
0\end{array}$ \\
\hline Mean & 341.02 & 433.69 & 436.22 & 437.89 & 31.32 & 42.98 & 48.17 & 45.50 & 269.50 & 321.74 & 327.93 & $\begin{array}{c}325.7 \\
4\end{array}$ \\
\hline \multirow[t]{2}{*}{$\mathrm{CD}_{0.05}$} & \multirow{2}{*}{\multicolumn{3}{|c|}{$\begin{array}{c}\mathbf{T} \\
\mathbf{S} \\
\mathbf{T x S}\end{array}$}} & 2.04 & \multirow{2}{*}{\multicolumn{3}{|c|}{$\begin{array}{c}\mathbf{T} \\
\mathbf{S} \\
\mathbf{T x S}\end{array}$}} & NS & \multirow{2}{*}{\multicolumn{3}{|c|}{$\begin{array}{c}\mathbf{T} \\
\mathbf{S} \\
\mathbf{T x S}\end{array}$}} & NS \\
\hline & & & & 2.93 & & & & 0.95 & & & & 2.60 \\
\hline
\end{tabular}


Combination of tree lopping and organic manure treatments was found to be nonsignificant with maximum available phosphorus in $\mathrm{T}_{0} \mathrm{~S}_{1}$ and $\mathrm{T}_{2} \mathrm{~S}_{0}$ attained minimum available phosphorus. Jeevamruth contains enormous amount of microbial load which multiply in the soil and acts as tonic to enhance microbial activity and acidic substances in soil (Palekar, 2006). Manjur et al., (2014) who reported significant difference in available soil phosphorus with radial distance from tree base under $F$. albida and $A$. tortilis in southern Ethiopia. Prasad et al., (2016) also reported similar results for tree density effect on soil organic carbon and available NPK.

Among the lopping treatments the tree lopping treatment $\mathrm{T}_{3}$ (75\% lopping) resulted in the minimum available potassium in soil $\left(\mathrm{kg}^{-1}\right.$ ha) i.e. $309.17 \mathrm{~kg}$ and the lopping treatment $\mathrm{T}_{0}(0 \%$ lopping $)$ resulted in the maximum available potassium in soil $\mathrm{kg}^{-1}$ ha) i.e. $312.80 \mathrm{~kg}$. Whereas the application of organic manures significantly affect the available potassium in soil $\left(\mathrm{kg}^{-1} \mathrm{ha}\right)$ among the organic manure treatments, the available potassium in soil $\left(\mathrm{kg}^{-1} \mathrm{ha}\right)$ was maximum in treatment $\mathrm{S}_{2}$ (Jeevamruth) i.e. $327.9 \mathrm{~kg}$ which was statistically at par with $\mathrm{S}_{3}$ (Vermicompost) i.e. $325.74 \mathrm{~kg}$ and the minimum available potassium in soil $\left(\mathrm{kg}^{-1} \mathrm{ha}\right)$ was attained in treatment $S_{0}$ (No manure) i.e. $269.5 \mathrm{~kg}$.

Combination of tree lopping and organic manure treatments was found to be nonsignificant with maximum available potassium in soil (kg-1 ha) being attained in treatment combination $\mathrm{T}_{0} \mathrm{~S}_{1}(0 \%$ lopping intensity + Jeevamruth) i.e. $329.4 \mathrm{~kg}$ and treatment combination $\mathrm{T}_{3} \mathrm{~S}_{0}(50 \%$ lopping intensity + No manure) attained minimum available potassium in soil $\left(\mathrm{kg}^{-1}\right.$ ha) i.e. 266.2kg. Abebe (2006) also reported similar results that exchangeable $\mathrm{K}$ concentration under the canopy of Millettia ferruginia was significantly higher.

In conclusion, soil physico-chemical properties were improved from initial to final crop harvest under agroforestry system due to presence of canopy and leaf fall whereas lopping has not shown significant effect on some of soil properties because the duration of experiment was less to observe alter in soil properties. But the lopping has shown immediate significant positive affect on crop yields hence cab be taken up. The availability of nutrients was high, when applied with organic manures in agroforestry system and also improved the crop yield. Hence more of the long duration studies are needed in order to study effect of canopy management on soil in agroforestry; this area needs to be studied further in future.

\section{References}

Abebe, N. 2006.Soil Fertility Status under Indigenous Tree Canopies on Farm land in Selected Areas of Eastern and Western Haragehe Zone. M.Sc. Thesis. Haramaya University, Haramaya:54-62

EmireAschalew and ZebeneAsfaw 2018: Status of Soil Properties Under Canopy of Farmers' Preferred Coffee Shade Tree Species, in AdolaRede District, Guji Zone, Southern Ethiopia. American Journal of Agriculture and Forestry; 6(5): 148-155

Gathala MK, Kanthaliya PC, Verma A and Chahan MS. 2007.Effect of integrated nutrient management on soil properties and humus fractions in the long-term fertilizer experiments. Journal of the Indian Society of Soil Science 53: 360363.

Gomez LA and Gomez AA. 1984. Statistical Procedure for Agricultural Research. John Wiley and Sons, Singapore. p 680. Jackson ML. 1973. Soil chemical analysis. 
Prentic Hall of India Pvt. Ltd. NewDelhi. pp. 151-153.

Kahi CH, Ngugi RK, Mureith SM, Ng'ethe JC. 2009. The canopy effects of Prosopis juliflora (dc.) and Acacia tortilis (hayne) trees on herbaceous plants species and soil physico-chemical properties in njemps flats, Kenya. Trop. Subtrop. Agroecosyst.10:441-449.

Kaushal R, Verma KS and Chaturvedi OP and Alam NM. 2012. Leaf litter decomposition and nutrient dynamics in four multipurpose tree species. Rangeland Management and Agroforestry 33; 20-27

Manjur B, Abebe T, Abdulkadi A. 2014. Effects of scattered $F$. albida (Del) and C. macrostachyus (Lam) tree species on key soil physicochemical properties and grain yield of Maize (Zea mays): A case study at umbulo Wacho watershed, southern Ethiopia. Southern Ethiop. J. Agric. Res. 3(3):63-73.

Merwin HD and Peech M. 1951.Exchangeability of soil potassium in sand, slit and clay fraction in influenced by the nature of complementary exchangeable cations. Soil Science Society of American. Poc. 15: 125-128.

Olsen R, Cole CV, Wantable FS and Dean LA. 1954. Estimation of available Pin soil by extraction with sodium bicarbonate, U.S. Deptt. Agricultural Citrcular 939: 19.

Palekar S. $2006 . \quad$ Shoonya bandovaladanaisargikakrushi pub. Swamy Anand, Agri Prakashana, Bangalore.

Prasad R, NewajR,Tripathi VD, Saroj NK, Singh P, Singh R, Ajit, Chaturvedi OP. 2016. Impact of Albizia procerabenth. based agroforestry system on soil quality in Bundelkhand region of Central India. Journal of Soil and Water Conservation. 15(3): 226-232.

Sirohi C and Bangarwa KS. 2015. Nutrient status of soil under different spacing of poplar (Populus deltoids) based agroforestry system in semi-arid region of Haryana. International journal of tropical agriculture 33: 111-118

Srikanth K, Srinivasamurthy CA, Siddaramappa R and Ramkrishna PVR. 2000. Direct and residual effect of enriched composts, FYM, vermicompost and fertilizers on properties of an alfisol. J. Indian Soc. Soil Sci. 48 (3): 496-499.

Subbiah BV and Asija GL. 1956.Rapid procedure for the estimation of available nitrogen in soil. Current Science. 25: 259-260.

Walkley AJ and Black IA. 1934. Estimation of soil organic carbon by chromic acid titration method. Soil Science 37: 29-38.

\section{How to cite this article:}

Shashi Kumar, M.C., C.L. Thakur, P.V. Dhanyashri, Stanzin Namdol and Inamatti, S.S. 2020. Studies on Effect of Tree Lopping Intensities and Organic Manures onSoil Physico - Chemical Properties in Morus-Maize Based Agroforestry System. Int.J.Curr.Microbiol.App.Sci. 9(06): 3661-3667. doi: https://doi.org/10.20546/ijcmas.2020.906.431 